\title{
Chromatographic measurement of nitrogen mineralization rates in marine coastal waters with ${ }^{15} \mathbf{N}$
}

\author{
Wayne S. Gardner ${ }^{1}$, James B. Cotner $\mathrm{Jr}^{1,2, \bullet}$, Lynn R. Herche ${ }^{1}$ \\ ${ }^{1}$ NOAA Great Lakes Environmental Research Laboratory. \\ ${ }^{2}$ Cooperative Institute for Limnology and Ecosystem Research, 2205 Commonwealth Blvd., Ann Arbor, \\ Michigan 48105, USA
}

\begin{abstract}
Isotope ratios for ammonium were determined directly on seawater filtrates by high performance liquid chromatography (HPLC) for isotope dilution and enrichment experiments in the Mississippi River plume region of the Gulf of Mexico. The 2 isotopic forms could be differentiated by cation exchange chromatography because the ratio of ${ }^{15} \mathrm{NH}_{4}{ }^{+}:{ }^{15} \mathrm{NH}_{3}$ is slightly greater than the ratio of ${ }^{14} \mathrm{NH}_{4}{ }^{+}:{ }^{14} \mathrm{NH}_{3}$ in aqueous solutions at $\mathrm{pH}$ 's near the $\mathrm{pK}$ for ammonium (ca $\mathrm{pH}$ 9). Relatively small (e.g $60 \mathrm{ml}$ ) water samples were fortified in the field with ${ }^{15} \mathrm{~N}$-ammonium or ${ }^{15} \mathrm{~N}$-amino acids and incubated at simulated in situ temperature and light conditions. At 2 to $13 \mathrm{~h}$ intervals, subsamples were filtered $(0.2 \mu \mathrm{m}$ pore size) and frozen for later HPLC analysis in the laboratory. Isotope-dilution experiments conducted on water samples collected from different depths in the plume indicated that maximum ammonium regeneration rates occurred in near-surface waters where phytoplankton and bacterial production rates are relatively high. Amino acid and ammonium concentration changes and ${ }^{15} \mathrm{~N}_{-} \mathrm{NH}_{4} \mathrm{com}$ positional changes were measured at 4 intervals over $21 \mathrm{~h}$ after the addition of an ${ }^{15} \mathrm{~N}$-labeled amino acid mixture $(4 \mu \mathrm{M})$. Comparison of the amount of ${ }^{15} \mathrm{~N}$ recovered as ${ }^{15} \mathrm{NH}_{4}$ to that removed from solution as ${ }^{15} \mathrm{~N}$-labeled amino acids indicated that the potential conversion of 'assimilated' ${ }^{15} \mathrm{~N}$-labeled amino acids to dissolved ammonium ranged from about $50 \%$ in surface water to about $90 \%$ in nearbottom ( $30 \mathrm{~m}$ depth) water. These results demonstrate the usefulness of the HPLC approach for measuring nitrogen regeneration rates or conversion efficiencies in small volumes of marine coastal waters.
\end{abstract}

\section{INTRODUCTION}

Community ammonium regeneration rates in aquatic systems are commonly determined by measuring changes in ammonium concentration and isotope ratios over time in water samples with added ${ }^{15} \mathrm{NH}_{4}$ (Harrison 1978, Blackburn 1979, Caperon et al. 1979). Estimating ammonium regeneration or amino acid nitrogen conversion rates by isotope dilution or enrichment is technically cumbersome because of the need to remove ammonium from the water, dry it, and convert it to $\mathrm{N}_{2}$ gas by high temperature combustion before isotope ratios of nitrogen can be determined by mass or emission spectrometry (Harrison 1983). Isolation of suf-

\footnotetext{
- Present address: Department of Wildlife and Fisheries Sciences, Texas A\&M University, College Station, Texas $77843-2258$, USA
}

ficient ammonium for mass analysis requires that ammonium be distilled (Harrison 1978, Caperon et al. 1979), extracted (Dudek et al. 1986, Selmer \& Sörensson 1986), precipitated (Fisher \& Morrissey 1985), or diffused (Blackburn 1979, Kristiansen \& Paasche 1989) from relatively large volumes of water. These approaches are susceptible to ${ }^{14} \mathrm{~N}$ contamination from reagents or the atmosphere and must often be corrected for this error (Selmer \& Sörensson 1986). Large samplesize requirements complicate field sample manipulations to isolate components of the mineralization process. Also, distillation, solvent extraction, and ammonium precipitation techniques are inconvenient to perform on research vessels or require the use of hazardous chemicals.

To understand nitrogen remineralization dynamics, it is useful to follow the specific fate (e.g. regeneration as ammonium versus accumulation into biomass) of ni- 
trogen from organic compounds such as amino acids Tracer studies of amino acids are often performed with ${ }^{14} \mathrm{C}$ - or ${ }^{3} \mathrm{H}$-labeled compounds rather than ${ }^{15} \mathrm{~N}$-labeled compounds (Coffin 1989, Fuhrman 1990, Nagata \& Kirchman 1991). These approaches are useful for examining the carbon dynamics of organic molecules but they do not provide unequivocal information about the fate of nitrogen in the labeled compounds. Independent measurement of nitrogen dynamics is important because the source and fate of carbon and nitrogen associated with these compounds are not necessarily stoichiometrically coupled in the microbial food web (Kirchman et al. 1989, 1990, Tupas \& Koike 1991).

A liquid chromatographic technique, recently introduced to directly analyze ${ }^{15} \mathrm{NH}_{4}:\left[{ }^{14} \mathrm{NH}_{4}+{ }^{15} \mathrm{NH}_{4}\right]$ ratios in seawater filtrates containing comparable concentrations of ${ }^{15} \mathrm{NH}_{4}$ and ${ }^{14} \mathrm{NH}_{4}$ (Gardner et al. 1991), can alleviate some of these technical problems. Although not suitable for tracer additions that are needed to accurately assess uptake rates (Glibert et al. 1982), this approach has potential advantages for field studies of ammonium regeneration rates including small sample size, few sample manipulations, and reduced probability for contamination.

In this paper, we improve the precision of the HPLC technique, apply it to field isotope addition experiments, and present depth profiles of ammonium regeneration rates and potential amino acid nitrogen conversion efficiencies at sites in the Gulf of Mexico Mississippi River plume. Community and bacterialspecific ammonium regeneration results for surface waters over a more extensive salinity gradient are presented in a companion paper (Cotner \& Gardner 1993).

\section{METHODS}

High performance liquid chromatographic analysis of ammonium nitrogen isotope ratios. Ammonium nitrogen isotope ratios were measured directly in seawater by injecting sample filtrates onto a high performance cation exchange column and measuring ammonium peak retention time shifts, relative to a standard, fluorometrically after post-column reaction of ammonium with 0 -phthalaldehyde/2-mercaptoethanol reagent. Retention time shift $\left(R T_{\text {shut }}\right)$ is here defined as the change in sample ammonium retention time, relative to that for natural abundance ammonium, that is caused by the presence of ${ }^{15} \mathrm{NH}_{4}$ in a sample (Gardner et al. 1991). Cation exchange fractionation of the 2 isotopic forms of ammonium is possible because a higher proportion of ${ }^{15} \mathrm{NH}_{4}$ than of ${ }^{14} \mathrm{NH}_{4}$ exists in the protonated form relative to the fraction in the non-ionic form at $\mathrm{pH}$ values in the general range of the
pK for ammonium (about $\mathrm{pH} 9$ ) in aqueous solutions (Ishimori 1960).

The assembled HPLC system (modification of Gardner et al. 1991) was designed to optimize the precision of chromatographic conditions, including mobile phase and reagent flow rates, column temperature, and time of injections. As previously described, the $30 \mathrm{~cm} \times 4 \mathrm{~mm}$ i.d. stainless steel column contained a strong cation-exchange resin $(5 \mu \mathrm{m}$ beads of sodiumform sulfonic acid cation exchanger with $12 \%$ crosslinked polystyrene/divinylbenzene polymeric matrix; St. John Associates, Beltsville, MD, USA). This column resin is very stable at the $\mathrm{pH}$ of our mobile phase $(\mathrm{pH}$ 10.3) and we have observed no deterioration of column performance after more than $2 \mathrm{yr}$ of use. The column was held at either 47 or $35^{\circ} \mathrm{C}$ with a Standard CROCO-CIL HPLC column heater. Mobile phase buffer was delivered at a flow rate of ca $0.14 \mathrm{ml} \mathrm{min}^{-1}$ with an ISCO 260D syringe pump operated at constant pressure (19.3 $\mathrm{mPa}$ ) and the post-column reagent was delivered at $0.10 \mathrm{ml} \mathrm{min}^{-1}$ with an Anspec 909 (now available as an Alcott 760) piston pump equipped with a microbore head. The reagent was degassed by vacuum immediately before use and a slow flow of helium was passed over the solution in the reservoir during pump operation to minimize flow variations caused by the presence of dissolved gases.

We automated the analytical system for continuous operation and took steps to improve its precision over that initially reported (Gardner et al. 1991). The manual injector valve was replaced with an Alcott Model 728 HPLC Autosampler (64 vial capacity) equipped with a VALCO Model EC6W fast-electrically-activated injector valve to provide rapid, precise injections and continuous operation. The sodium borate mobile phase buffer (pH 10.3) and OPA reagent were prepared as in Gardner et al. (1991) except that the surfactant, Brij ( $30 \%$ solution), was added to both the mobile phase

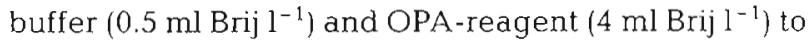
lubricate the HPLC pump seals. The mobile phase buffer contained ethylenediaminetetraacetic acid (EDTA) to prevent seawater cations from accumulating on the column. A new calibration curve was prepared with each buffer preparation of 21 .

The application of constant pressure to the Brijlubricated buffer improved precision over that obtained in the 'constant-flow' mode because it minimized any variations in flow rate that could otherwise be caused by slight leakage around the syringe pump seal. All buffers and samples were filtered $10.2 \mu \mathrm{m}$ pore size nylon filters) before delivery to the column to prevent potential changes in back pressure.

To compare sample retention time to that of standard ammonium, 3 sequential injection vials were loaded as follows for each sample measurement: first and second 
vials with $4 \mu \mathrm{M}$ standard ammonium (natural isotope abundance) prepared in mobile phase buffer and the third vial with a seawater filtrate from an isotope dilution experiment. Up to 21 sample sets (triplicate injections for each of 7 sample filtrates) were loaded into the autosampler at one time. For each sample injection, the autosampler was programed to make sequential injections at 0,3.0 and 8.0 min to accomodate the 2 standard solutions and the sample filtrate respectively. Because our autosampler had 0.8 min delay between injections, the time sequences after injection were programmed at $2.2 \mathrm{~min}$ for the first standard, $4.2 \mathrm{~min}$ for the second standard, and $40 \mathrm{~min}$ for the sample filtrate in each sample set. This arrangement allowed the standard and sample ammonium ion to elute before the first standard of the next sample set was injected. The sample $\mathrm{RT}_{\text {shuf }}$ value was obtained by subtracting the ammonium retention time recorded for the second standard from that of the sample, after making the 5.0 min correction for the difference in injection times.

The $R T_{\text {shift }}$ for the 2 standard solutions injected sequentially before each sample served as a quality assurance indicator. Differences in retention times for these standards were generally within the range of $0 \pm 0.03$ min. If the retention times for the standards in a sample set differed by more than $0.05 \mathrm{~min}$, the $\mathrm{RT}_{\text {shit }}$ value for the sample was rejected. However, because results were almost never rejected when the syringe pump was operated in the 'constant-pressure' mode, we have recently modified the procedure to eliminate the first standard and now inject only a single standard solution $5.0 \mathrm{~min}$ before each sample injection. With this modification, the reprogrammed autosampler can be loaded with up to 32 samples and be operated automatically for $>24 \mathrm{~h}$ without service. $\mathrm{RT}_{\text {shift }}$ results for 3 replicate injections were averaged to obtain each data point. Standard errors of the mean for $\mathrm{RT}_{\text {shuf }}$ values from replicate samples were about $0.01 \mathrm{~min}$ on average and were similar to values observed for integrator peak detection error (i.e. the mean difference between $\mathrm{RT}_{\text {shift }}$ results from 2 integrators connected in parallel to receive the same detector signal: 0.009 min; Gardner et al. 1991).

Calibration standards, prepared in sea water, and corresponding samples were run under 1 of 2 sets of chromatographic conditions depending on the experimental treatment. (1) For isotope dilution experiments with added ${ }^{15} \mathrm{NH}_{4}$, the column was held at $47^{\circ} \mathrm{C}$ and the mobile phase buffer was pumped through the column at a constant pressure of $19.3 \mathrm{mPa}$ to provide a flow rate of ca $0.14 \mathrm{ml} \mathrm{m^{-1 }}$ and an ammonium retention time of ca 36 min. (2) For ${ }^{15} \mathrm{~N}$ - amino acid addition experiments, the column temperature was lowered to $35^{\circ} \mathrm{C}$, to facilitate separation of ammonium from added arginine, and the mobile phase pressure was increased to $23.8 \mathrm{mPa}$. Under these conditions, the flow

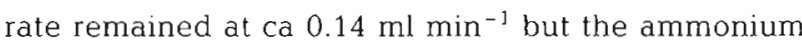
retention time was about $47 \mathrm{~min}$. For these samples, the sample time interval on the autosampler was programmed at 50 instead of 40 min to accomodate the increased retention time for ammonium ion.

The mathematical model to describe the calibration curves was modified from our previous model to fit the data points more accurately (see 'Results and Discussion'). Isotope ratios for ammonium in isotope dilution samples were determined from the calibration curves by reverse prediction as previously described (Gardner et al. 1991).

Sample site description. Samples were collected from the RV 'Pelican' at 3 sites in the Mississippi River plume region of the Gulf of Mexico in September 1991 (Table 1). Water temperatures of experimental waters ranged from 29 to $30^{\circ} \mathrm{C}$ (Toon \& Dagg 1992). The Mississippi River plume region includes areas of high phytoplankton production as nutrients from Mississippi River water are introduced into regions of relatively low sediment load (Lohrenz et al. 1990). Water for isotope dilution or enrichment experiments was collected from 0 to $0.5 \mathrm{~m}$ below the surface with a clean plastic bucket or at other depths with Niskin bot tles mounted on a rosette sampler (General Oceanics) equipped with a Seabird CTD package.

Field procedure for isotope dilution experiments. For field isotope dilution experiments, $60 \mathrm{ml}$ of sea water were placed in a clean transparent bottle and mixed after addition of 4 (or 2) $\mu \mathrm{M}{ }^{15} \mathrm{NH}_{4} \quad$ (98\%; Sigma). The addition of above-tracer levels of ${ }^{15} \mathrm{NH}_{4}$ could potentially have increased ammonium regenera-

Table 1. Location, maximum depth, and salinity range, from surface to bottom waters, for 3 sites sampled in the Gulf of Mexico Mississippi River plume in September 1991

\begin{tabular}{|ccccc|}
\hline Site & Latitude & Longitude & $\begin{array}{c}\text { Maximum depth } \\
(\mathrm{m})\end{array}$ & $\begin{array}{c}\text { Salinity range } \\
(\% \circ)\end{array}$ \\
\hline 011 & $28^{\circ} 42.86^{\prime} \mathrm{N}$ & $89^{\circ} 41.69^{\prime} \mathrm{W}$ & 88 & $24.61-36.47$ \\
012 & $28^{\circ} 42.37^{\prime} \mathrm{N}$ & $89^{\circ} 42.36^{\prime} \mathrm{W}$ & 90 & $25.77-36.47$ \\
028 & $28^{\circ} 48.29^{\prime} \mathrm{N}$ & $90^{\circ} 05.96^{\prime} \mathrm{W}$ & 34 & $30.99-33.62$ \\
\hline
\end{tabular}


tion rate estimates slightly during bottle incubations if phytoplankton growth rates and organic substrate release rates increased in response to the addition of ammonium (Selmer 1988). The bottles were placed in a deck-top incubator (Lohrenz et al. 1988), under approximately in situ temperature and light conditions, and subsamples were collected at intervals over total incubation periods of 4 to $21 \mathrm{~h}$. At each sampling interval, the bottles were gently mixed and about $9 \mathrm{ml}$ of water was removed and passed through a $0.2 \mu \mathrm{m}$ poresize nylon filter. The first $2 \mathrm{ml}$ rinsed the filter and the remainder was collected in an ammonium-free $8 \mathrm{ml}$ vial (Wheaten No. 224984). A portion of filtrate was analyzed for ammonium and primary amine concentrations (Gardner \& St. John 1991) on the research vessel and the rest was frozen for later HPLC analysis in the laboratory. Alternatively, ammonium concentration as well as isotope ratios could be calculated from HPLC analysis of the thawed filtrates (Gardner et al. 1991). Ammonium regeneration rates were calculated from changes in ammonium concentrations and isotope ratios over measured time intervals using the Blackburn/Caperon model (Blackburn 1979, Caperon et al. 1979).

Amino acid addition experiment. An amino acid addition experiment was conducted on water samples from 3 depths at Site 028. The objectives of this experiment were: (1) to examine the ability of the HPLC technique to follow ${ }^{15} \mathrm{~N}$ isotope enrichment over time in samples with added ${ }^{15} \mathrm{~N}$-labeled amino acids, and (2) to examine the extent of conversion of the added amino acid- ${ }^{15} \mathrm{~N}$ to ammonium (versus incorporation into biomass) at the different depths. A surface $(0.5 \mathrm{~m})$ sample was filtered ( $1 \mu \mathrm{m}$ pore size) to investigate the effects of particles larger than bacteria on the dynamics or extent of amino acid mineralization. This sample and unfiltered samples taken at depths of $0.5,6$ and $30 \mathrm{~m}$ were each fortified with $4 \mu \mathrm{M}\left(4.69 \mu \mathrm{g}\right.$-at. $\left.{ }^{15} \mathrm{~N} \mathrm{l}^{-1}\right)$ of ${ }^{15} \mathrm{~N}$-labeled amino acids (MSD Isotopes Algal Amino Acid Mixture $-{ }^{15} \mathrm{~N}$ ) and incubated for ca $21 \mathrm{~h}$. Subsamples were removed at 4 time points during the incubation and analyzed for ammonium and amino acid concentrations and ${ }^{15} \mathrm{NH}_{4}:\left[{ }^{14} \mathrm{NH}_{4}+{ }^{15} \mathrm{NH}_{4}\right]$ ratios.

\section{RESULTS AND DISCUSSION}

\section{Methodological modifications}

Automation and improvements to the precision of the HPLC procedure made this approach convenient and effective for the measurement of ammonium regeneration rates in coastal regions. Although the HPLC instrumentation for isotope ratio determination could potentially be taken to the field (Gardner et al.
1991), we did not do so because the time required for HPLC analysis of isotope ratios limited the number of samples that could be run during field investigations. However, filtration and freezing of a large number of samples on-board is feasible because only small filtrate volumes (e.g. 5 to $10 \mathrm{ml}$ ) are required for multiple HPLC injections.

Precision of the original HPLC method (Gardner et al. 1991) was improved by adding the surfactant, Brij, to the mobile phase buffer and post column reagent, switching the mobile phase syringe pump to a constant-pressure mode, averaging results from triplicate

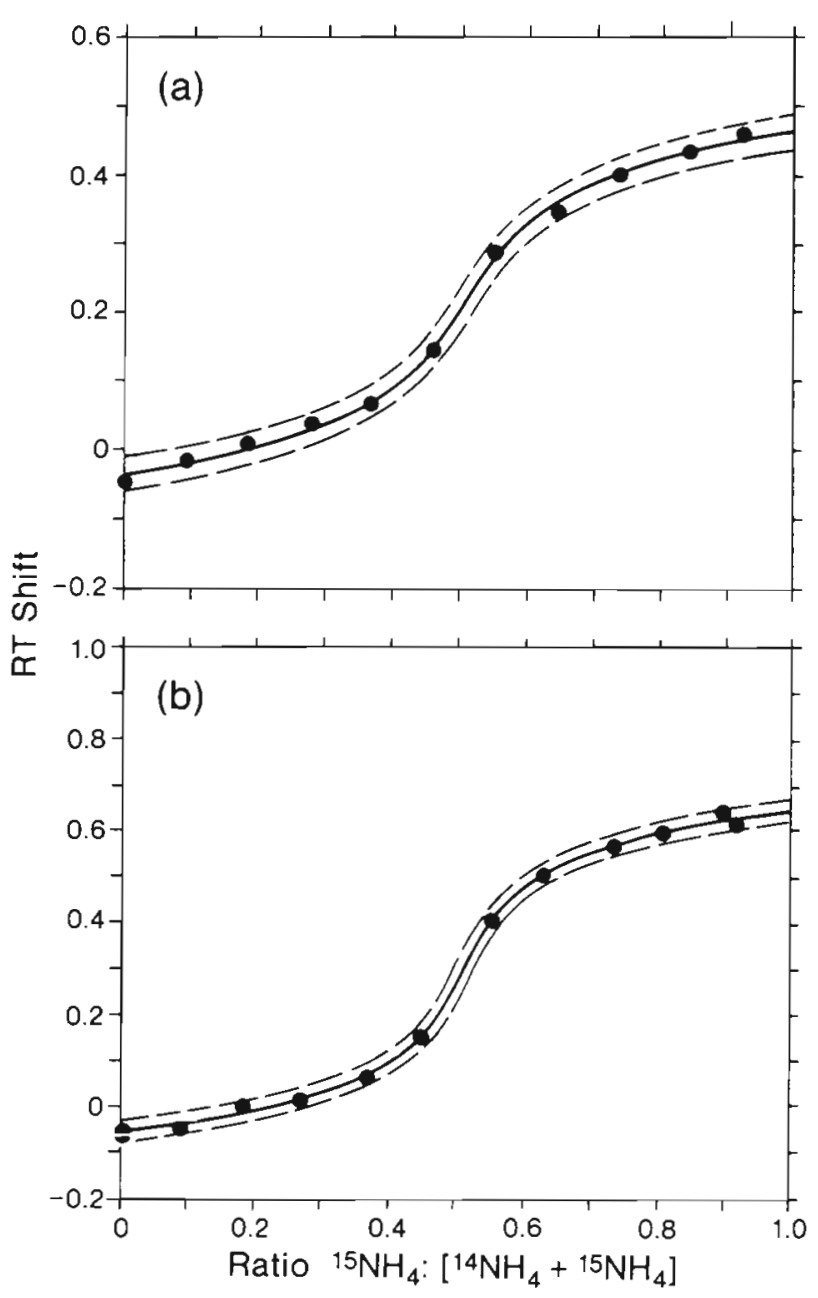

Fig. 1. Representative calibration curves with $95 \% \mathrm{Cl}$ under 2 sets of chromatographic conditions. (a) was obtained with the column temperature held at $47^{\circ} \mathrm{C}$ and a mobile phase buffer pressure of $19.3 \mathrm{mPa}$. These conditions were normally used when arginine was not present in the sea water samples (i.e. samples with only ${ }^{15} \mathrm{NH}_{4}$ added) because arginine coeluted with ammonium. (b) was obtained with the column held at $35^{\circ} \mathrm{C}$ and a mobile phase pressure of $23.8 \mathrm{mPa}$. This curve was used when ${ }^{15} \mathrm{~N}$-amino acids were added because, under these conditions, peaks for ammonium and arginine were completely resolved (e.g. Fig. 2a) 
injections for each sample filtrate, and improving the fit of the calibration curve to the observed $\mathrm{RT}_{\text {shift }}$ data.

Calibration curves (Fig. 1a, b) fit the empirical data well with tight confidence intervals when defined by the model described below. Different chromatographic conditions were used for samples with only ${ }^{15} \mathrm{NH}_{4}$ added (Fig. 1a) than for samples fortified with ${ }^{15} \mathrm{~N}$-amino acids (Fig. 1b). In the latter case, it was necessary to separate ammonium from the basic amino acid, arginine (e.g. Fig. 2a), that is not normally found in untreated sea water (Gardner \& St. John 1991). Smooth sigmoid-shaped calibration curves were obtained in both cases but the shapes of the curves were slightly different (Fig. 1).

The improved analytical precision obtained in this study (Fig. 1), over that originally reported (Gardner et al. 1991), revealed some aspects of our sigmoid curve model that could be modified to improve the accuracy and precision of analysis. To fit the data more closely, the cumulative standard normal distribution function, $\Phi(\cdot)$, previously used to model the data, was replaced by members of the following family that have increasingly 'long' tails as $\alpha$ approaches 0.5 from above:

$$
\begin{aligned}
& F_{\alpha}(X)=\frac{1}{C} \int_{-x}^{X} \frac{\mathrm{d} X}{\left(1+X^{2}\right)^{\alpha}} \\
& \text { where } C=\int_{-\infty}^{\infty} \frac{\mathrm{d} X}{\left(1+X^{2}\right)^{\alpha}} \text { and } \alpha>0.5 .
\end{aligned}
$$

The data for both curves were well described (Fig. 1) by the following revised model with $\alpha=0.54$ as applied in the relation

$$
S=a+b F_{a}(c+\mathrm{d} R)+\epsilon
$$

where $S$ is the $\mathrm{RT}_{\text {shuft }} R$ is the ${ }^{15} \mathrm{NH}_{4}:\left[{ }^{15} \mathrm{NH}_{4}+{ }^{15} \mathrm{NH}_{4}\right]$ ratio; $a, b, c, d$ and $\alpha$ are fitted parameters; and $\epsilon$ is a random error term.

\section{Field ammonium regeneration measurements}

Depth-distributions of ammonium regeneration rates at Sites 011 and 012, measured over incubation periods of ca $2 \mathrm{~h}$, indicate that the regeneration rates decreased rapidly with depth within the upper portion of the water column (Fig. 3). The co-occurrence of high ammonium regeneration rates (Fig. 3) and bacterial production rates (Chin-Leo \& Benner 1992, Cotner \& Gardner 1993) in the upper photic zone where phytoplankton are relatively abundant (Lohrenz et al. 1990)

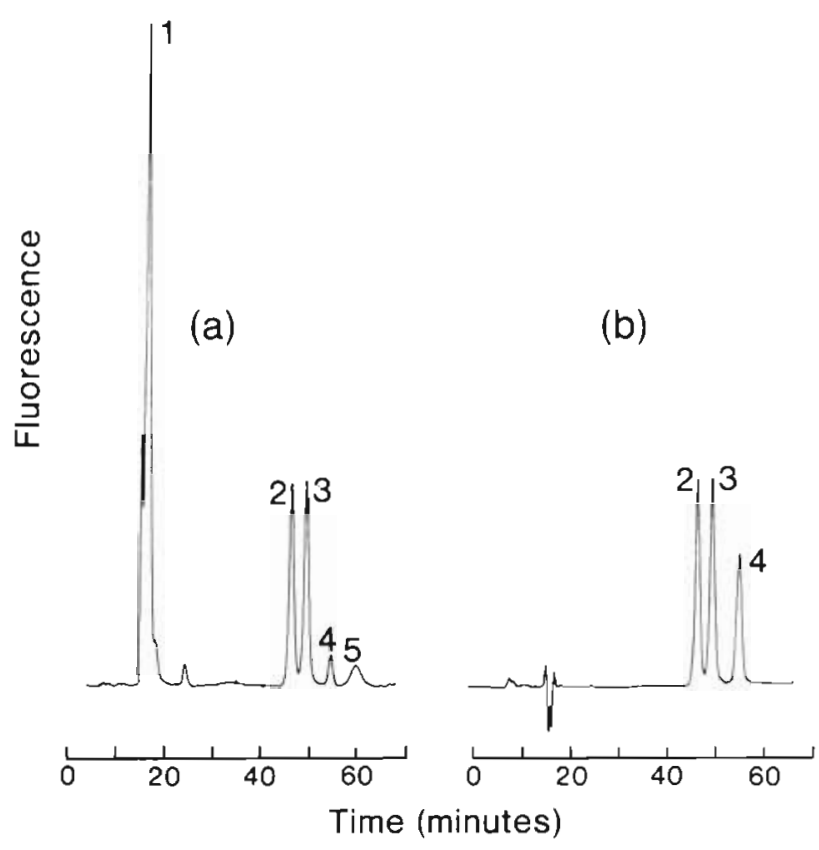

Fig. 2. Chromatograms of seawater filtrates sampled at the beginning $(a ; 0 h)$ and end $(b ; 21.3 h)$ of an amino acid enrichment experiment. The sample was fortified with $4 \mu \mathrm{M}{ }^{15} \mathrm{~N}$ labeled amino acids $\left(4.69 \mu \mathrm{g}\right.$-at. $\left.{ }^{15} \mathrm{~N} \mathrm{l}^{-1}\right)$ before the first sampling. The ammonium $\mathrm{RT}_{\text {shifts }}$ (i.e. the difference in retention times between peaks 4 and 3 ) were $-0.012 \mathrm{~min}$ for (a) and 0.598 min for (b). Peak 1: dissolved free amino acids in fortified seawater sample; Peaks 2 and 3:4 $\mu \mathrm{M} \mathrm{NH} \mathrm{NH}_{4}$ in mobile phase buffer respectively injected at 8.0 and $5.0 \mathrm{~min}$ before the sea water sample; Peak 4: ammonium in seawater sample; Peak 5: arginine in fortified sea water sample

is consistent with the hypothesis that ammonium regeneration rates are closely associated with primary production processes in coastal waters (Harrison 1978). This interaction may be mediated in part by bacterial consumption of labile organic nitrogen compounds, such as free amino acids, that are likely released by phytoplankton (Keil \& Kirchman 1991, Cotner \& Gardner 1993). Supply rates of labile dissolved organic nitrogen compounds were apparently not as high in subsurface waters with low phytoplankton activity as in the surface plume waters. Use of incubators with approximately in situ light conditions (Lohrenz et al. 1988) is important for multi-hour ${ }^{15} \mathrm{NH}_{4}$ incubation experiments because ammonium regeneration rates may be affected by changes in organic substrate release rates by phytoplankton, that in turn would likely be affected by changes in light and temperature.

\section{Amino acid addition experiment}

Ammonium concentrations, amino acid concentrations and the isotope ratios of dissolved ammonium 


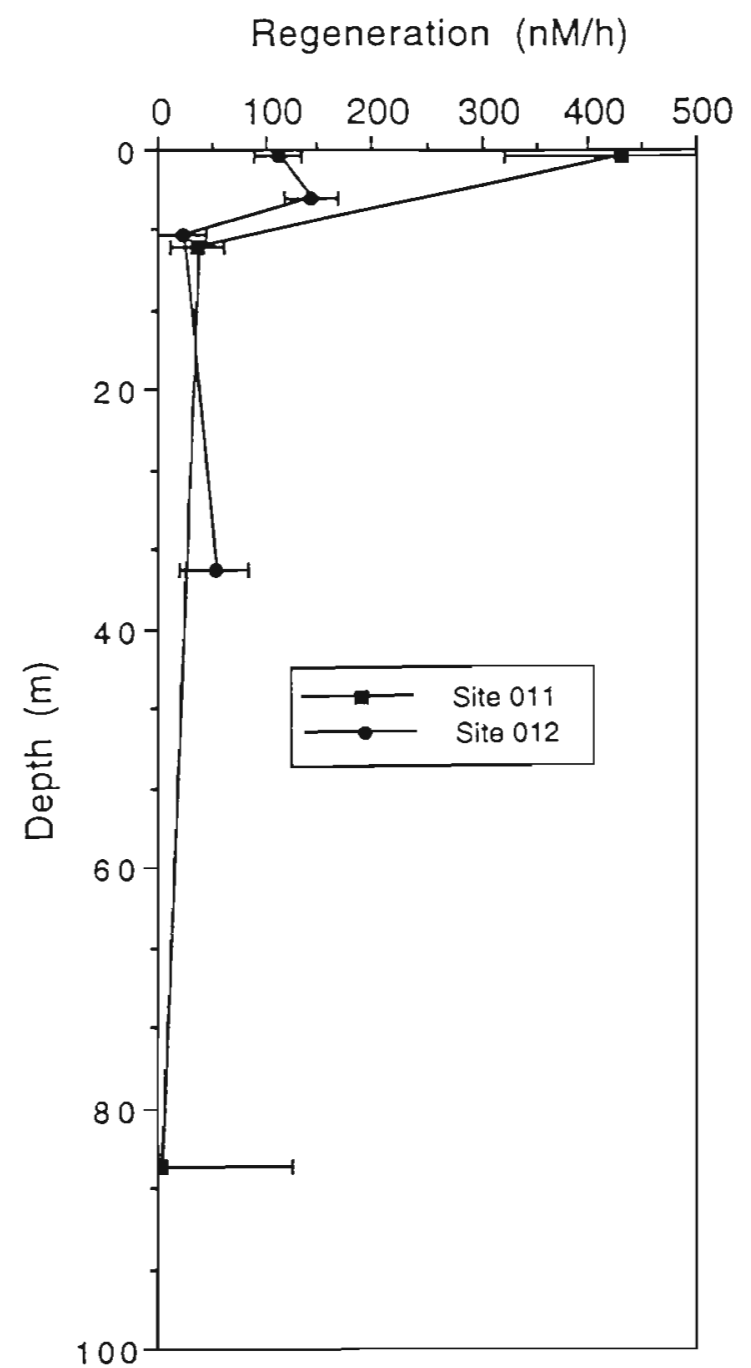

Fig. 3. Ammonium regeneration rate depth profiles at Sites 011 and 012

were determined over 3 intervals during the incubation for the samples with added ${ }^{15} \mathrm{~N}$-amino acids (Fig. 4). Representative chromatograms for the filtered surface samples at 0 and $21 \mathrm{~h}$ after addition of the ${ }^{15} \mathrm{~N}$ amino acid mixture (Fig. 2) illustrate changes in amino acid and ammonium concentrations during the experiment and show how the ammonium retention time increased as the ammonium became enriched with ${ }^{15} \mathrm{NH}_{4}$ during the incubation. In the unfiltered surface sample, neither concentrations of ammonium or amino acids nor ${ }^{15} \mathrm{NH}_{4}:\left[{ }^{14} \mathrm{NH}_{4}+{ }^{15} \mathrm{NH}_{4}\right]$ ratios changed substantially during the first $8 \mathrm{~h}$ of incubation. However, in the filtered surface sample, the amino acid concentration had begun to decrease and the ${ }^{15} \mathrm{~N}$ content of ammonium had increased after $8 \mathrm{~h}$ of incubation (Fig. 4). The difference between the filtered and unfiltered surface sample treatments was probably caused by in-

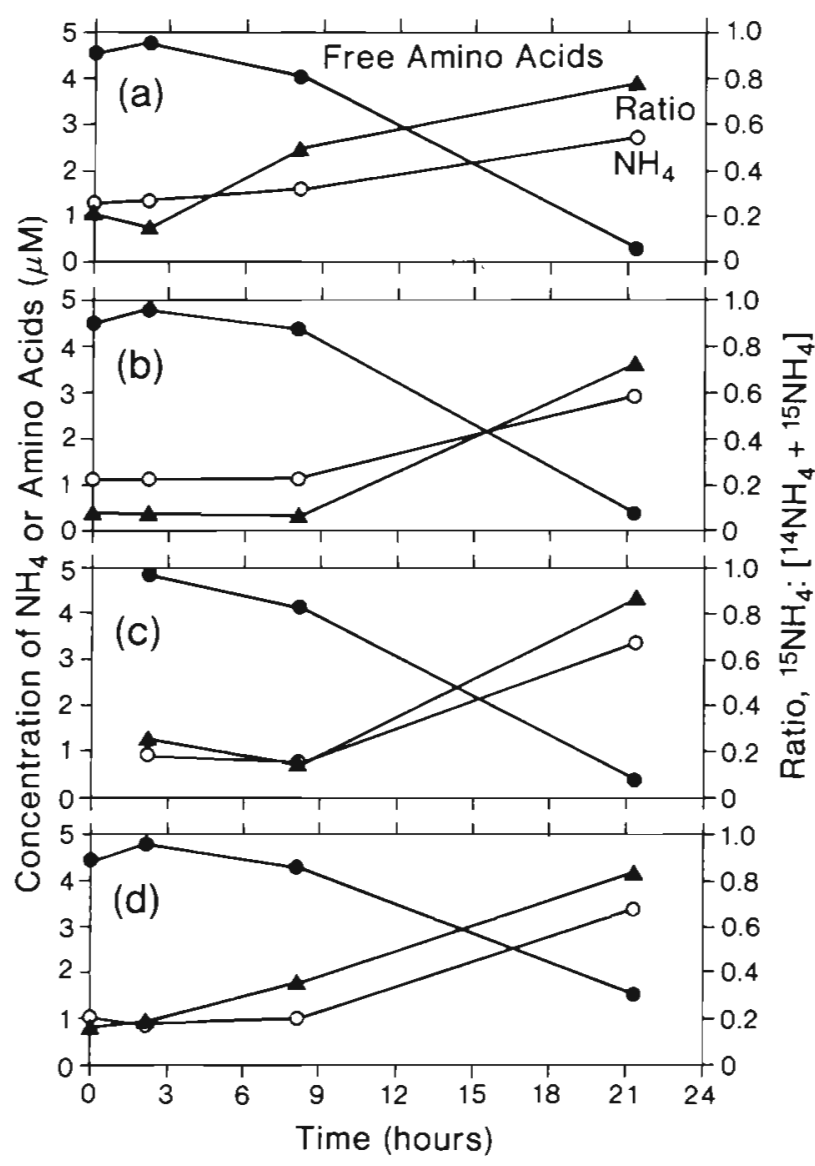

Fig. 4. Time course curves of amino acid and ammonium concentrations and of measured isotope ratios of ${ }^{15} \mathrm{NH}_{4}:{ }^{15} \mathrm{NH}_{4}+$ ${ }^{15} \mathrm{NH}_{4}$ ] in samples that were fortified with $4 \mu \mathrm{M}{ }^{15} \mathrm{~N}$-amino acids ( $=4.69 \mu \mathrm{g}$-at. ${ }^{15} \mathrm{~N} \mathrm{I}^{-1}$ ) from a labeled algal hydrolysate. (a) $0.5 \mathrm{~m}$ depth, filtered (1 $\mu \mathrm{m}$ pore size); (b) $0.5 \mathrm{~m}$ depth, unfiltered; (c) $6 \mathrm{~m}$ depth, unfiltered; (d) $30 \mathrm{~m}$ depth, unfiltered

creased bacterial production in the filtered sample as a result of removing bacterial grazers (Keil \& Kirchman 1991). In the third interval, between 8 and $21 \mathrm{~h}$, amino acids were depleted to near background levels in all the samples except for the $30 \mathrm{~m}$ sample that still contained $1.5 \mu \mathrm{M}$ of 'free amino acids'. Ammonium concentrations increased and became enriched with ${ }^{15} \mathrm{~N}$ in all the samples. The increased rates of amino acid removal and ammonium accumulation observed in the third interval over that observed in the first 2 intervals may indicate that the bacterial community responded to the added amino acids by increasing metabolic activity and/or growth rates.

To estimate the percentage of amino acid nitrogen that was converted into ammonium, we calculated the ratios of ${ }^{15} \mathrm{~N}$ concentrations accumulated as ammonium (i.e. ammonium concentration times the ${ }^{15} \mathrm{~N}$ isotope ratio) after $21 \mathrm{~h}$ to those originally added as amino acids and also to the amounts of ${ }^{15} \mathrm{~N}$-amino acids that 
Table 2. Percent conversion of amino acid- ${ }^{15} \mathrm{~N}$ to ammonium after $21 \mathrm{~h}$ incubation under conditions simulating natural temperature and light. Each sample was initially fortified with $4 \mu \mathrm{M}$ of an ${ }^{15} \mathrm{~N}$-labeled amino acid mixture containing $4.69 \mu \mathrm{g}$. at. ${ }^{15} \mathrm{~N}$. The ratios in column A were calculated as a percent of the total ${ }^{15} \mathrm{~N}$ added as amino acids, whereas the ratios in column $B$ were calculated based on measured decreases in dissolved amino acid concentrations assuming no isotope dilution of the amino acid pool during the incubation. The actual percent conversion should fall between these 2 extremes

\begin{tabular}{|c|c|c|}
\hline Sample depth & $\begin{array}{c}\text { A } \\
\text { Percent of added } \\
{ }^{15} \mathrm{~N} \text {-labeled amino } \\
\text { acids recovered as } \\
{ }^{15} \mathrm{NH}_{4}\end{array}$ & $\begin{array}{c}\text { B } \\
\text { Percent of 'assimi- } \\
\text { lated' }{ }^{15} \mathrm{~N} \text {-labeled } \\
\text { amino acids } \\
\text { recovered as }{ }^{15} \mathrm{NH}_{4}\end{array}$ \\
\hline \multicolumn{3}{|l|}{$0.5 \mathrm{~m}$} \\
\hline \multicolumn{3}{|l|}{ Filtered } \\
\hline Unfiltered & 45 & 49 \\
\hline \multicolumn{3}{|l|}{$6 \mathrm{~m}$} \\
\hline Unfiltered & 63 & 69 \\
\hline \multicolumn{3}{|l|}{$30 \mathrm{~m}$} \\
\hline Unfiltered & 60 & 91 \\
\hline
\end{tabular}

were removed from solution over the same interval (Table 2). For the purpose of the latter calculation, the fraction of dissolved free amino acids labeled with ${ }^{15} \mathrm{~N}$ was assumed to remain constant during the incubation (i.e. negligible isotope dilution of the dissolved free amino acid pool). The first method provides conservative estimates of percent amino acid- $\mathrm{N}$ mineralization because it does not account for any ${ }^{15} \mathrm{~N}$ remaining in solution as dissolved free amino acids. The second method of calculating ratios yields maximal conversion values because the assumption of negligible isotope dilution of dissolved amino acids during the incubation is likely not valid (Fuhrman 1987, 1990). The 2 calculations yielded similar ratios for all of the treatments except for the $30 \mathrm{~m}$ sample that still contained $1.5 \mu \mathrm{M}$ of dissolved amino acids at the end of the experiment. In the surface waters, about 48 to $49 \%$ of the assimilated' amino acid- ${ }^{15} \mathrm{~N}$ was recovered as ${ }^{15} \mathrm{NH}_{4}$, whereas in the deeper waters up to $91 \%$ of the 'assimilated' amino acid- ${ }^{15} \mathrm{~N}$ was recovered as ${ }^{15} \mathrm{NH}_{4}$. In agreement with our surface water results, about $43 \%$ of amino acid- ${ }^{15} \mathrm{~N}$ removed from solution was recovered as ${ }^{15} \mathrm{NH}_{4}$ in surface waters of the subarctic Pacific (Kirchman et al. 1989). From 50 to $70 \%$ of the DON taken up by surface water bacteria was mineralized to ammonium in Ohtsuchi Bay and Aburatsubo Bay, Japan (Tupas \& Koike 1991).

Our results suggest that added amino acids were more efficiently incorporated into biomass in the surface samples than in the deeper samples where most of the 'assimilated' amino acid- ${ }^{1.5} \mathrm{~N}$ was converted into dissolved ammonium (Table 2). An explanation for the apparent change in mineralization efficiency with depth is that more labile organic carbon (e.g. Kirchman et al. 1991), released by phytoplankton or other organisms, was available in the surface waters than in the deep waters. The conclusion that available organic carbon was present in surface waters was also supported by a linear relationship between ammonium uptake rate and abundance of added bacteria in surface water from Site 012 (Cotner \& Gardner 1993). Alternate carbon sources could provide energy that would allow the bacteria to incorporate relatively high amounts of natural or added amino acids or ammonium directly into biomass. On the other hand, if other sources of carbon were not as available, the bacteria would need to use more of the amino acid carbon for energy and therefore would deaminate a higher proportion of the assimilated amino acids and release the nitrogen as ammonium (Hollibaugh 1978, Billen 1984, Zehr et al. 1985, Goldman et al. 1987).

The above example indicates that HPLC analysis can be effectively used to estimate ${ }^{15} \mathrm{~N}$ isotope enrichment patterns in waters with relatively high levels of added ${ }^{15} \mathrm{~N}$-amino acids. Although the rates or conversion efficiencies obtained from these measurements must be considered to be potential rather than actual values, sample site or depth comparisons provide insight into the potential efficiencies of bacteria in using amino acids in the different waters. This information is important because amino acids are major substrates for bacteria in coastal marine systems (Coffin 1989, Fuhrman 1990, Keil \& Kirchman 1991, Cotner \& Gardner 1993). Similarly, the HPLC approach could potentially be used to examine production of ${ }^{15} \mathrm{NH}_{4}$ from other labeled compounds (e.g. nitrate, proteins, or other forms of dissolved organic nitrogen) or labeled particulate organic matter (e.g algae or detritus) in aquatic microcosms.

\section{CONCLUSIONS}

Liquid chromatographic measurement of isotope ratios can efficiently provide estimates of ${ }^{15} \mathrm{NH}_{4}:\left[{ }^{14} \mathrm{NH}_{4}+\right.$ ${ }^{15} \mathrm{NH}_{4}$ ] isotope ratio changes in marine coastal waters fortified with either added ${ }^{15} \mathrm{NH}_{4}$ or ${ }^{15} \mathrm{~N}$-amino acids and incubated under approximately natural light and temperature conditions. Incubation under near-natural light conditions is important for ${ }^{15} \mathrm{~N}$-addition experiments because it simulates natural in situ conditions for phytoplankton production, with associated organic substrate release, over the relatively long intervals (hours) needed for measurable isotope ratio changes to occur. 
Improvements in analytical precision and in mathematical curve definition, over that originally described (Gardner et al. 1991), now allow the estimation of ${ }^{15} \mathrm{NH}_{4}:\left[{ }^{14} \mathrm{NH}_{4}+{ }^{15} \mathrm{NH}_{4}\right]$ ratios over the entire range of the sigmoid calibration curve. Major advantages of the HPLC technique, over mass or emission spectrometry methods for measuring the isotopic composition of ammonium-N, are the small sample size requirement < $<5 \mathrm{ml}$ required for replicate HPLC injections as compared to 50 to $500 \mathrm{ml}$ per sample for mass analysis), minimal sample handling before analysis, and reduced chances for contamination with ${ }^{14} \mathrm{~N}$ from the atmosphere or reagents (Gardner et al. 1991). Direct measurement of isotope ratios in small samples makes the HPLC approach ideal for observing the effects of experimental manipulations, such as bacterial additions (Cotner \& Gardner 1993), on ammonium regeneration rates. The method is not suitable for tracer additions of ${ }^{15} \mathrm{~N}$-lableled compounds (e.g. $<10 \%$ of ambient ammonium concentrations) because comparable concentrations of the 2 isotopes, and total ammonium concentrations of at least $0.5 \mathrm{mM}$, are required for accurate determination of isotope ratio changes (Gardner et al. 1991). These requirements preclude the described method from being effective in measuring ammonium regeneration in offshore oceanic or other oligotrophic waters where the amounts of ammonium regenerated over several hours are low relative to the amounts of ${ }^{15} \mathrm{~N}$ added.

The HPLC method is particularly attractive for measuring ${ }^{15} \mathrm{NH}_{4}$ accumulation in waters fortified with other ${ }^{15} \mathrm{~N}$-labeled compounds. For example, we were able to follow progressive isotope enrichment of ${ }^{15} \mathrm{NH}_{4}$ after the addition of ${ }^{15} \mathrm{~N}$-labeled amino acids to water samples. In these treatments, one can estimate the comparative mineralization efficiencies of added amino acids at different sites and estimate accumulation as biomass versus release as ammonium. These data, combined with radioactive tracer estimates of amino acid-carbon turnover rates, should provide needed information about the comparative dynamics of carbon and nitrogen from dissolved free amino acid pools in marine coastal ecosystems.

Acknowledgements. This research was supported by the National Oceanic and Atmospheric Administration through the Coastal Ocean Program Office. We thank S. Lohrenz for providing the decktop incubators, the crew of the RV 'Pelican' for help in collecting samples, R. Heath and R. Keil for their comments on an earlier version of the manuscript, and $G$. Lang and $D$. James for graphics support. This paper is GLERL Contribution No. 807

\section{LITERATURE CITED}

Billen, G. (1984). Heterotrophic utilization and regeneration of nitrogen. In: Hobbie, J. E., Williams, P. J. LeB. (eds.)
Heterotrophic activity in the sea. Plenum Press, New York, p. $313-365$

Blackburn, T. H. (1979). Method for measuring rates of $\mathrm{NH}_{4}{ }^{+}$ turnover in anoxic marine sediments using a ${ }^{15} \mathrm{~N}_{-} \mathrm{NH}_{4}{ }^{+}$ dilution technique. Appl. environ. Microbiol. 37: 760-765

Caperon, J., Schell, D., Hirota, J., Laws, E. (1979). Ammonium excretion rates in Kaneohe Bay, Hawaii, measured by a ${ }^{15} \mathrm{~N}$ isotope dilution technique. Mar. Biol. 54: 33-40

Chin-Leo, G., Benner, R. (1992). Enhanced bacterioplankton production and respiration at intermediate salinities in the Misssissippi river plume. Mar. Ecol. Prog. Ser. 87: 87-103

Coffin, R. B. (1989). Bacterial uptake of dissolved free and combined amino acids in estuarine waters. Limnol. Oceanogr. 34: 531-542

Cotner, J. B., Gardner, W. S. (1993). Heterotrophic bacterial mediation of nitrogen and carbon fluxes in the Mississippi River plume. Mar. Ecol. Prog. Ser. 93: 75-87

Dudek, N., Brezinski, M. A., Wheeler P. A. (1986). Recovery of ammonium nitrogen by solvent extraction for the determination of relative ${ }^{15} \mathrm{~N}$ abundance in regeneration experiments. Mar. Chem. 18: 59-69

Fisher, T. R., Morrissey, K. M. (1985). A new method for the recovery of ammonium from natural waters for measurement of ${ }^{15} \mathrm{~N}$ composition in isotope dilution experiments. Mar. Chem. 16: 11-21

Fuhrman, J. A. (1987). Close coupling between release and uptake of dissolved free amino acids in sea water studied by an isotope dilution approach. Mar. Ecol. Prog. Ser. 37 : $45-52$

Fuhrman, J. A. (1990). Dissolved free amino acid cycling in an estuarine outflow plume. Mar. Ecol. Prog. Ser. 66: 197-203

Gardner, W. S., Herche, L. R., St. John, P. A., Seitzinger, S. P. (1991). High performance liquid chromatographic determination of ${ }^{15} \mathrm{NH}_{4}:\left[{ }^{14} \mathrm{NH}_{4}+{ }^{15} \mathrm{NH}_{4}\right]$ ion ratios in seawater for isotope dilution experiments. Anal. Chem. 63: 1838-1843

Gardner, W. S., St. John, P. A. (1991). High-performance liquid chromatographic method to determine ammonium ion and primary amines in seawater. Anal. Chem. 63:537-540

Glibert, P. M., Lipschultz, F., McCarthy, J. J., Altabet, M. A. (1982). Isotope dilution models of uptake and remineralization of ammonium by marine plankton. Limnol. Oceanogr. 27: 639-650

Goldman, J. C., Caron, D. A., Dennett, M. R. (1987). Regulation of growth efficiency and ammonium regeneration in bacteria by substrate $C: N$ ratio. Limnol. Oceanogr. 32 : $1239-1252$

Harrison, W. G. (1978). Experimental measurements of nitrogen remineralization in coastal waters. Limnol Oceanogr. 23: 684-694

Harrison, W. G. (1983). Nitrogen in the marine environment IV.2 Use of isotopes. In: Carpenter, E. J., Capone, D. G. (eds.) Nitrogen in the marine environment. Academic Press, New York, p. 763-807

Hollibaugh, J. T. (1978). Nitrogen regeneration during the degradation of several amino acids by plankton communities collected near Halifax, Nova Scotia, Canada. Mar. Biol. 45: 191-201

Ishimori, T. (1960). The nitrogen isotope equilibrium between ammonia and ammonium ion. Bull. chem. Soc. Japan 33: 516-519

Keil, R. G., Kirchman, D. L. (1991). Contribution of dissolved free amino acids and ammonium to the nitrogen requirements of heterotrophic bacterioplankton. Mar. Ecol. Prog. Ser. 73: 1-10

Kirchman, D. L., Keil, R. G., Wheeler, P. A. (1989). The effect 
of amino acids on ammonium utilization and regeneration by heterotrophic bacteria in the subarctic Pacific. Deep Sea Res. 36: 1763-1776

Kirchman, D. L., Keil, R. G., Wheeler, P. A. (1990). Carbon limitation of ammonium uptake by heterotrophic bacteria in the subarctic Pacific. Limnol. Oceanogr. 35: 1258-1266

Kirchman, D. L., Suzuki, Y., Garside, C., Ducklow, H. W. (1991). High turnover rates of dissolved organic carbon during a spring phytoplankton bloom. Nature 352: 612-614

Kristiansen, S., Paasche, E. (1989). An improved method for determining relative ${ }^{15} \mathrm{~N}$ abundance in ammonium regeneration studies by direct diffusion. Mar. Ecol. Prog. Ser. 54 203-207

Lohrenz, S, E,, Dagg, M. J., Whitledge, T. (1990). Enhanced primary production at the plume/oceanic interface of the Mississippi River. Cont. Shelf Res. 10: 639-664

Lohrenz, S. E., Wiesenburg, D. A., DePalma, I. P., Johnson, K. S., Gustafson, D. E. Jr (1988). Interrelationships among primary production, chlorophyll, and environmental conditions in frontal regions of the western Mediterranean Sea. Deep Sea Res. 35: 793-810

This article was presented by B. \& E. Sherr, Corvallis, Oregon, USA
Nagata, T., Kirchman, D. L. (1991). Release of dissolved free and combined amino acids by bacterivorous marine flagellates. Limnol. Oceanogr. 36: 433-443

Selmer, J. S. (1988). Ammonium regeneration in eutrophicated coastal waters of Sweden. Mar. Ecol. Prog. Ser. 44 265-273

Selmer, J. S., Sörensson, F. (1986). New procedure for extraction of ammonium from natural waters for ${ }^{15} \mathrm{~N}$ isotopic ratio determinations. Appl. environ. Microbiol. 52: $577-579$

Toon, R., Dagg, M. (1992). Nutrient enhanced coastal ocean productivity program (NECOP) data report: CTD and hydrographic data R/V 'Pelican' Cruise, September 12-18, 1991 Louisiana Marine Consortium Data Report No. 14, Chauvin

Tupas, L., Koike, I. (1991) Simultaneous uptake and regeneration of ammonium by mixed assemblages of heterotrophic marine bacteria. Mar. Ecol. Prog. Ser. 70: 273-282

Zehr, J. P., Axler, R. P., Goldman, C. R. (1985). Heterotrophic mineralization of amino acid nitrogen in subalpine Castle Lake, California. Mar. Chem. 16: 343-350

Manuscript first received: July 17, 1992

Revised version accepted: December 7, 1992 